\title{
Memory Integration Processes in Benign Childhood Epilepsy with Centrotemporal
}

\section{Spikes}

\author{
Kárpáti Judit ${ }^{1}$, Kónya Anikó ${ }^{1}$, Donauer Nándor ${ }^{2}$ \\ ${ }^{1}$ Eötvös Loránd University, Institute of Psychology, Department of Cognitive Psychology \\ ${ }_{2}^{2}$ St. John Hospital and North-Buda Unified Hospitals
}

\begin{abstract}
Benign childhood epilepsy with centrotemporal spikes (BECTS) is the most frequent focal epilepsy in children, however the pattern of affected memory processes is still controversial. In the present study, we report a systematic investigation of working memory processes in children with BECTS. The applied method consisted of single-modality tasks (spatial or verbal) and a combined-modality task (spatial-verbal). Performance was compared to a group of healthy children matched for age, sex and IQ level. Our results show no difference between BECTS and control group in single-modality tasks, however BECTS children differed significantly from controls in the combined-modality task, which included multiple binding processes (integration of what, where and when). These findings suggest that automatic memory processes are not affected, however, conscious memory integration may be difficult for children with BECTS. Our results imply no specific memory dysfunction in BECTS but suggest difficulties in organizing information within memory and possible frontal lobe disturbances.
\end{abstract}

Keywords: BECTS, contextual memory, verbal-visual binding, automatic and conscious memory processes

\section{INTRODUCTION}

Benign childhood epilepsy with centrotemporal spikes (BECTS) is the most common childhood focal epileptic syndrome. The general manifestations are focal sensomotor seizures during sleep. Seizures occur between the ages of 3 and 13, and resolve spontaneously during puberty. BECTS was defined for many years as a completely benign syndrome without any cognitive or intellectual deficits (referencia). 
In the recent years, neuropsychological research has demonstrated that BECTS is not entirely a benign condition. Neuropsychological studies of BECTS report deficits in visuo-motor skills (Heijbel \& Bohman, 1975; D’Alessandro et al., 1990; Giordani et al., 2006; Pinton et al., 2006; Ay et al., 2009; Danielsson and Petermann, 2009), language and reading abilities (D'Alessandro et al., 1990; Ay et al., 2009; Danielsson and Petermann, 2009; Goldber-Stern et al., 2010; Verotti et al., 2011), memory and learning (Weglage et al., 1997; Croona et al., 1999; Giordani et al., 2006; Northcott et al., 2005, 2007; Pinton et al., 2006; Danielsson and Petermann, 2009) and executive functions (D’Alessandro et al., 1990; Croona et al., 1999; Giordani et al., 2006; Pinton et al., 2006; Ay et al., 2009).

Previous research on memory functions in BECTS report conflicting results. While some studies have not found memory deficits (e. g. D'Alessandro et al., 1990; Ay et al., 2009), several studies have reported extensive memory difficulties in children with BECTS (e. g. Croona et al., 1999; Northcott et al., 2007; Danielsson and Petermann, 2009). Furthermore, some researchers argue that verbal and spatial memory processes are equally affected in BECTS (Northcott et al., 2007; Danielsson and Petermann, 2009) while others found only verbal (Croona et al., 1999) or visuo-spatial memory difficulties (Giordani et al., 2006).

Among these conflicting reports, there are some convergent findings. It seems that the majority of the studies have not found memory deficits in a/the digit span test (D'Alessandro et al., 1990; Croona et al., 1999; Ay et al., 2009), and in a block span test (D’Alessandro, 1990; Croona et al., 1999; Goldberg-Stern, 2009), only Goldberg-Stern et al. (2009) reported lower digit span in BECTS. These results suggest that children with BECTS have no deficits in single-modality tasks (only verbal or only spatial) where they only need to maintain items.

In complex memory tasks, however, the results are more contradictory. Mit jelent ebben a kontextusban az, h complex task? Hogy hosszú? Hogy több a modalitás? First, we summarize the results of the studies where verbal memory tasks were used. While D'Alessandro et al. (1990) and Goldberg-Stern et al. (2009) have not found memory deficit in the Rey Auditory Verbal Learning Test (RAVLT), Croona et al. (1999) report that children with BECTS have impaired performance in this test. Vago et al. (2008) have found deficits in the California Verbal Learning test but only in children with BECTS younger than 10 years. In a story recall test Goldberg-Stern et al. (2009) have not observed differences between BECTS children and controls while Croona et al. (1999) report lower performance in children with BECTS. Finally, Danielsson and Petermann (2009) found sentence memory deficit in children with BECTS. 
In complex visuo-spatial tasks, the results are also controversial. Northcott et al. (2007) and Danielsson et al. (2009) report picture memory deficit in BECTS. In the Rey-Osterrieth Complex Figure Test Godberg-Stern et al. (2009) and Croona et al. (1999) have not found differences between the BECTS group and controls. Weglage et al. (1997) report difficulties in a picture location task (Central Learning Exercise). Finally Völkl-Kernstock et al. (2006) have observed memory deficits in tasks involving the reconstruction of spatial figures?

Taken together, these results suggest that BECTS children's performance seems more vulnerable in complex meaningful tasks where they need to organize information from multiple resources in memory than when they only need to maintain items. In the framework of Baddeley's modified working memory model (see e. g. Baddeley, 2009) children with BECTS might have deficits in complex working memory tasks, but not in single-modality STM (shortterm memory) tasks (e.g. digit span, block span).

In the present study, our aim was to investigate working memory functions in BECTS by comparing performances across single-modality- (verbal or spatial) and combined-modality tasks (verbal-spatial). We created a computerized method in order to assess performance in simple and complex memory tasks A single-modality uaz, mint a simple? Jobb lenne uazzal a kifejezessel maradni. The peripheral miert peripheral? single-modality tasks measured spatial memory span (what and where), verbal memory span (what and when), and spatial sequential memory span (where and when) while the combined-modality task assessed performance in multiple binding of what, where and when which involves the integration of verbal as well as spatial and sequential? information. Fentebb esetleg tisztazni lehetne, h ebben a kontextusban mit jelent az, hogy modality (verbal, spatial, sequential?). De lehet, h cask en kovetem nehezen...

In our recent study (Kárpáti, Király and Kónya, 2013) in healthy children (between the ages of 6 and 10) and young adults, we demonstrated that multiple binding of what, where and when is an effortful process which relies on conscious attention, while memory binding within a single modality (spatial or verbal) might be a more automatic process. Esetleg ideirni, hogy milyen alapon lehetett eldönteni, hogy automatikus vagy tudatos a folyamat? Pl.: in our recent study, where the measure was response time... ) Based on these results, we find that this method (which method? Presenting multiple- and single binding tasks, ugye? Érdemes ismételni, mert új bekezdés) is suitable for assessing automatic and consciousness working memory binding processes. 
Our goal is to provide a systematic investigation of memory integration processes in children with BECTS. Based on previous research, we do not expect memory deficits in peripheral (ismét, hogy mi itt a peripheral?) single-modality tasks (spatial, verbal or spatial sequential). However we expect impaired memory performance in complex (non-peripheral, central? Érdemes uazt a szókincs családot alkalmazni- vagyis a peripheral ellentettjét, ha releváns) combined-modality which require the integration of multiple information.

\section{METHOD}

\section{Participants}

The sample consisted of 12 children ( 4 girls and 8 boys) aged 6 to 13 with BECTS (M age=9,35; $\mathrm{SD}=2,69)$ and 12 healthy children ( $\mathrm{M}$ age=9,35; $\mathrm{SD}=2,65)$ matched as closely as possible for age, sex and IQ level (esetleg t-test alapján volt szignifikáns eltérés a két populáció között vmelyik vonatkozásban?). Lehet esetleg: Please see Appendix for a table with the descriptive statistics of the two groups. Children with BECTS were recruited from St. John Hospital and North-Buda Unified Hospitals and their diagnosis was based on typical centrotemporal EEG pattern and clinical manifestations. Nine of the epileptic children were treated with antiepileptic drugs such as sulthiame (Ospolot) or levetiracetam (Keppra). Control group was collected from an elementary school in the same district as the hospital. Children with a history of neurological or psychiatric disorder were not included. All parents gave a written informed consent before their child participated in the study. The study was approved by the Ethics Committee of Hungarian Psychological Association.

\section{Measures}

\section{Psychometric tests - végülis minden teszt pszichometriai, nem? Inkább Intellectual and}

\section{Memory Skills Tests}

$\underline{\text { Verbal intellectual abilities }}$

Verbal subtests of the fourth edition of Wechsler Intelligence Scale for Children (WISC-4, 2003), adapted on a Hungarian sample by Nagyné Réz et al. (2008) were used. Verbal 
intelligence quotient (VIQ) was estimated from Similarities, Vocabulary and Comprehension subtests.

\section{$\underline{\text { Nonverbal intellectual abilities }}$}

Raven Progressive Matrices were used for estimating non-verbal intellectual abilities. Coloured Progressive Matrices (1990) were given to children below 11 years and Standard Progressive Matrices (1996) were administered to older children. Esetleg ideírni, hogy hány ilyen és hány olyan gyerek volt, ezt bele lehet tenni a táblázatba is az Appendixbe, a Descriptive Statistics táblába).

\section{$\underline{\text { Children's Memory Scale }}$}

Children's Memory Scale (Cohen, 1997) is an assessment of visuo-spatial learning and memory for children and adolescents between the ages 5 to 16 years. 3 of the 9 subtests were used as control tasks for visuo-spatial short-term memory (Descriptions of the subtests are presented in the Appendix).

\section{Experimental tasks}

Computerized binding tasks, originally developed by Postma, were used for measuring spatiotemporal memory span. In such tasks... és akkor leírni, hogy mi az elve a binding taskoknak. We modified the original task by... by modifying the original method of Postma et al. (2006). Pictures were selected from IPNP norm (Bates et al., 2003; Székely et al., 2004). Tehát esetleg egy-egy mondatot arról, hogy mi az a binding task és hogy mi az original paradigm, illetve pontosan miben lett módosítva.

Spatial task (what and where): Randomly selected pictures appear simultaneously in various locations on the screen and disappear after $5000 \mathrm{msec}$. Immediately after the presentation the previously presented pictures reappear aligned on the top of the screen and black dots mark their original positions. Participant has to relocate the objects to their original positions.

Verbal task (what and when): Randomly selected pictures appear serially in the center of the screen. Each item appears for $1500 \mathrm{msec}$. Right after the presentation the same pictures reappear on the top of the screen. Participant has to put the objects into a box in the centre of the screen in the original temporal order. 
Spatial sequential task (where and when): Randomly selected pictures appear serially in various locations on the screen. Each item appears for $1500 \mathrm{msec}$. Immediately after the presentation black dots appear simultaneously in the positions of previously presented objects. Participant has to click on the dots in the order the objects were presented initially.

Combined task (what, where and when): The presentation phase is the same as in the previous task. The same pictures reappear on the top of the screen and black dots mark their original positions. Participant has to relocate the exact objects in the original temporal order and to place them to the original positions.

(The presentation and recall phases of the tasks are presented in Table 1. The instructions of the tasks can be found in the Appendix)

Figure 1. Presentation and recall phases of binding tasks

\begin{tabular}{|c|c|c|}
\hline Task's name & Presentation & Recall \\
\hline Spatial & $\begin{array}{l}\text { simultaneous } \\
\text { sis }\end{array}$ & $\begin{array}{l}\text { spatial modality? Uakkor két } \\
\text { modalitás van itt is, mert elö } \\
\text { kell hívni a tárgy nevét és } \\
\text { helyét is, vagyis nem tudom, } \\
\text { a single modality jó-e, } \\
\text { kivéve, ha a binding } \\
\text { irodalmában már így } \\
\text { honosodott és csak én nem } \\
\text { értettem- esetleg fentebb egy } \\
\text { mondatot erröl, ahol már } \\
\text { jelöltem. }\end{array}$ \\
\hline Verbal & serial & $\begin{array}{c}1 \\
\text { verbal order }\end{array}$ \\
\hline
\end{tabular}




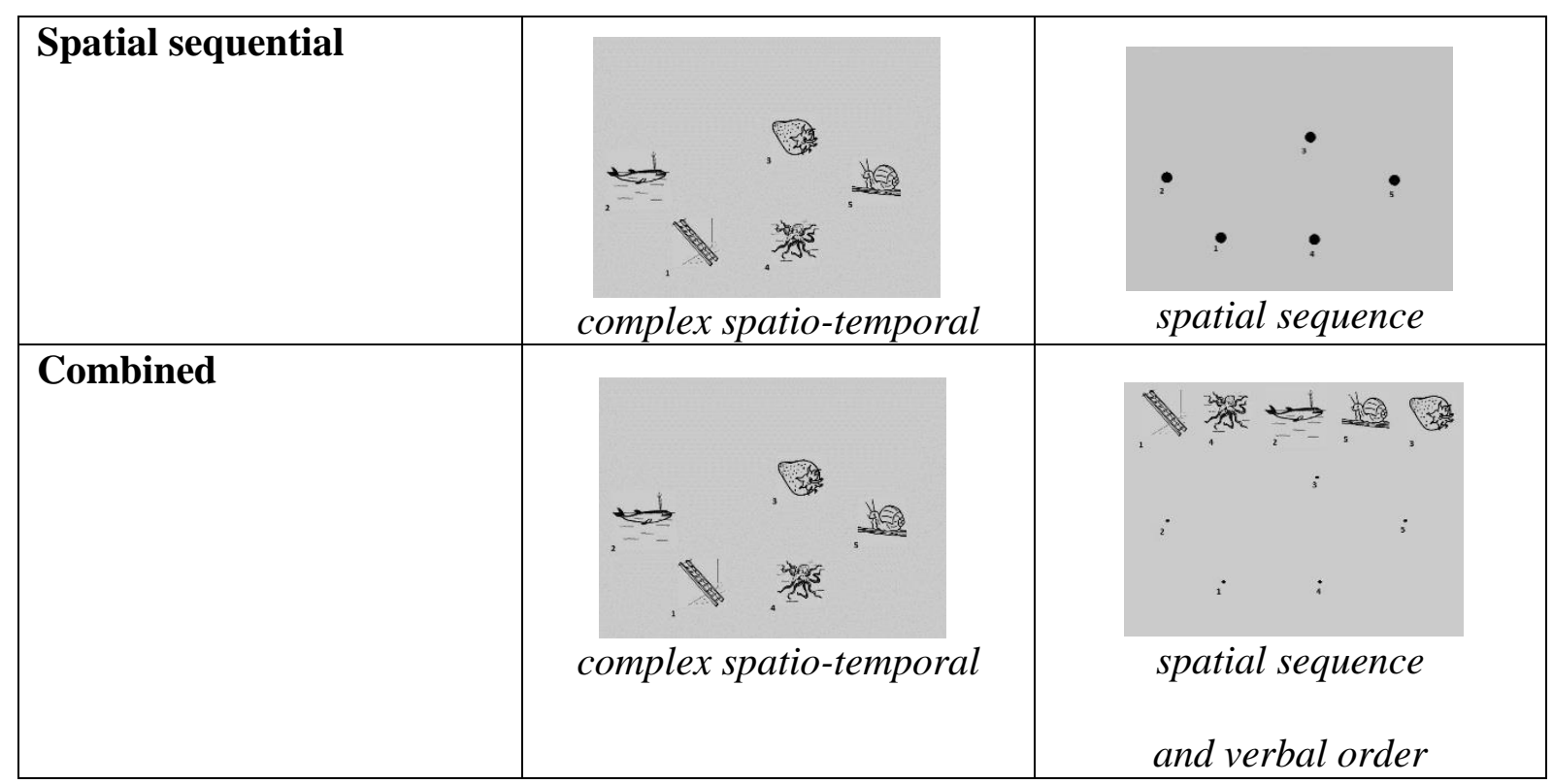

\section{Procedure}

All subjects participated in two sessions on two different days within a period of two weeks. One of the sessions included the computerized binding tasks and the other one included the standardized tasks (CMS, Raven, WISC-4). All sessions took place in a small and quiet room of the hospital or the school (in case of the control group). Both sessions took around an hour per person.

Scoring in the experimental tasks?

Experimental tasks: All participants completed the tasks in the same order (spatial, verbal, spatial sequential, combined) because of the successive nature of the method. In the beginning and in the end of the session we used a control task in order to assess fatigue, which may occur during the sessions (The description and the instruction of the control task is presented in the Appendix). Before each task, the examiner instructed the participant verbally. Two practice trials were given prior to each task to ensure that the subjects understood the verbal instructions. All four tasks started with the presentation of two objects. After every trial, the sequence was increased with one object (up to a maximum of ten objects). In the beginning of each trial, a countdown directed attention to the screen. There was no time limit in the trials. At the end of each trial the participant had to click on the box labeled 'finished' in order to start the next trial. At the end of the tasks a colored picture (with stars and the moon) appeared on the screen. 
Psychometric tests. In this session participants completed the intelligence tests (WISC-4 and Raven) and the tasks of the CMS. In order to maintain subjects' attention, verbal and visual tasks were given alternately. Before each task, the examiner instructed the participant verbally. At the end of the session the examiner thanked the child for participating in the study.

\section{Data analysis}

Data analysis was based on the scores obtained in the standardized tasks and the memory span score of the four memory binding tasks. Memory span was defined by the highest level that the participant had completed with not more than three errors. Before performing comparisons of the groups, the distribution of the data and the homogeneity of variances were checked. Data were not normally distributed within groups; therefore Mann-Whitney U tests were performed. P-values of $<0.05$ were considered to be statistically significant. Effect size indicators were estimated $(r=\mathrm{Z} / \sqrt{ } \mathrm{N})$.

\section{RESULTS}

There were no differences in verbal intelligence quotient (WISC-4) or in Raven progressive matrices performance between BCTE and control group. There were also no significant differences between BCTE and control group in the CMS subtests (dot locations, family pictures and picture locations) (The results of the standardized tests are presented in Table 1.)

Table 1. Group comparisons of intellectual abilities and CMS

\begin{tabular}{|l|c|c|c|c|c|}
\hline \multicolumn{1}{|c|}{ Measure } & BCTE & Control & Z & P & Effect size $^{\mathrm{b}}$ \\
\hline WISC4 - VIQ & $111,33(12,83)$ & $114,75(11)$ & $-0,52$ & 0,63 & 0,10 \\
\hline Raven & $103,08(10,17)$ & $106,08(11,85)$ & $-0,60$ & 0,55 & 0,12 \\
\hline $\begin{array}{l}\text { CMS - Dot } \\
\text { locations }\end{array}$ & $22,67(5,22)$ & $23(7)$ & $-0,29$ & 0,79 & $-0,05$ \\
\hline $\begin{array}{l}\text { CMS - Family } \\
\text { pictures }\end{array}$ & $39,58(6,47)$ & $40,33(4,55)$ & $-0,31$ & 0,75 & $-0,06$ \\
\hline $\begin{array}{l}\text { CMS - Picture } \\
\text { locations }\end{array}$ & $41,67(19,89)$ & $42,83(19,78)$ & $-0,66$ & 0,51 & $-0,13$ \\
\hline
\end{tabular}

Note: WISC4-VIQ: Wechsler Intelligence Scale for Children (4 ${ }^{\text {th }}$ edition) - Verbal intelligence quotient; Raven: Raven Progressive Matrices; CMS = Children's Memory Scale;

${ }^{a}$ Untransformed means are reported for clarity; ${ }^{\mathrm{b}} \mathrm{r}=\mathrm{Z} / \sqrt{ } \mathrm{N}$ 
Regarding performances in the binding tasks, we found no differences between BECTS children and controls in three of the four computerized binding tasks (spatial, verbal and spatial sequential). However, BECTS children performed significantly worse than control group in the combined task $(Z=-2,28 p ;<0,05)$. Finally we found no difference between performance of control tasks which implies that the cause of BECTS children's weak performance in combined task is not due to fatigue. (The results of the binding tasks are presented in Table 2. and in Figure 2.)

Table 2. Group comparisons of computerized binding tasks

\begin{tabular}{|l|c|c|c|c|c|}
\hline \multicolumn{1}{|c|}{ Task } & BECTS & Control & $\mathbf{Z}$ & P & ${\text { Effect } \text { size }^{\mathrm{b}}}$ \\
& $\mathrm{M}(\mathrm{SD})^{\mathrm{a}}$ & $\mathrm{M}(\mathrm{SD})^{\mathrm{a}}$ & & & \\
\hline Spatial & $6,92(1,44)$ & $6,67(1,23)$ & $-0,84$ & 0,44 & $-0,17$ \\
\hline Verbal & $5,83(1,03)$ & $6,08(1,37)$ & $-0,87$ & 0,41 & $-0,17$ \\
\hline Sequential & $6,08(0,99)$ & $6,42(0,90)$ & $-0,90$ & 0,41 & $-0,18$ \\
\hline Combined & $3,50(0,90)$ & $4,50(1,08)$ & $\mathbf{- 2 , 2 8}$ & $\mathbf{p}<\mathbf{0 , 0 5}$ & $\mathbf{- 0 , 4 6}$ \\
\hline
\end{tabular}

Note: ${ }^{a}$ Untransformed means are reported for clarity; ${ }^{\mathrm{b}} \mathrm{r}=\mathrm{Z} / \sqrt{ } \mathrm{N}$;

Figure 2. Memory span in binding tasks in the two groups

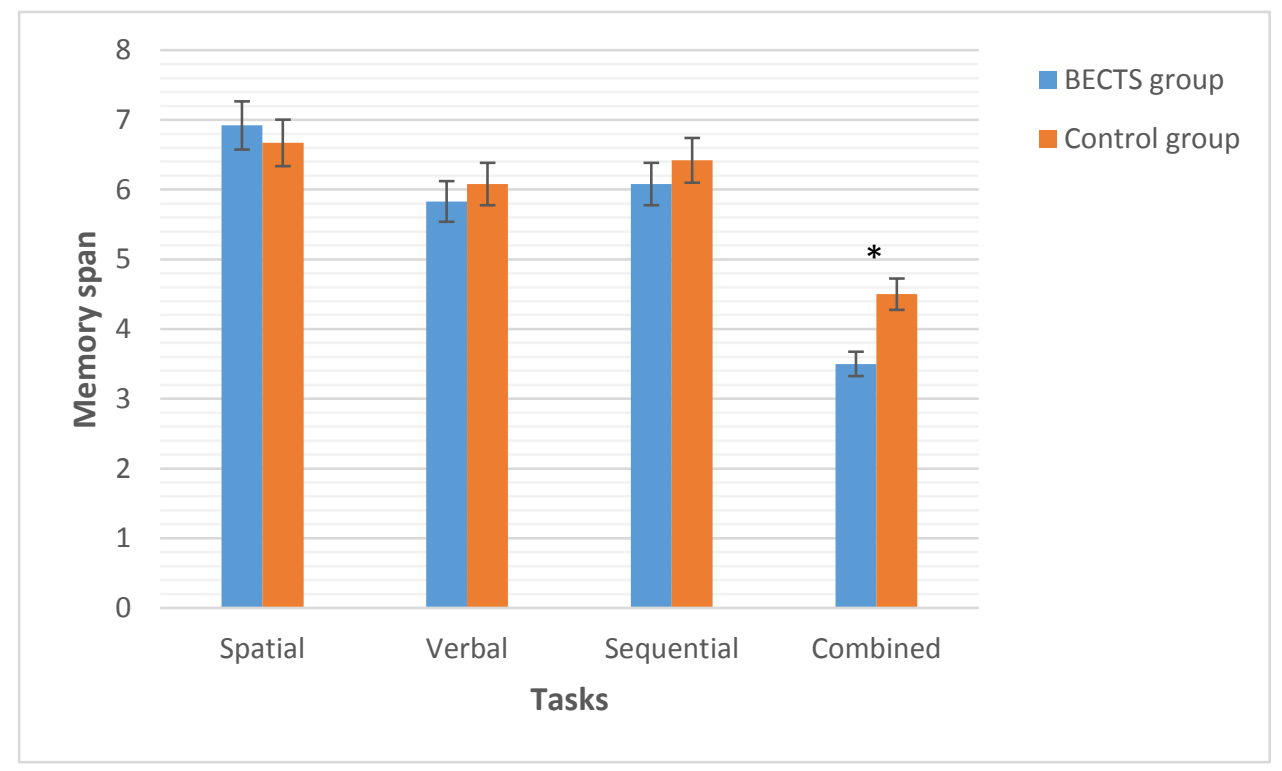

Note: Error bars show $95 \%$ CI for mean. BECTS: Benign childhood epilepsy with centrotemporal spikes, $*=p<0,05$. 
Our aim was to perform a systematic exploration of memory integration processes in BECTS. We examined BECTS children's spatial and verbal memory components separately and jointly in binding tasks. The single-modality tasks measured spatial memory span (what and where), verbal memory span (what and when), and spatial sequential memory span (where and when) while the combined-modality task assessed performance in multiple binding of what, where and when. This method allowed us to measure automatic and conscious integration processes in memory of children with BECTS. Erre ki kell térni, hogy honnan tudni, hogy mi automatikus és mi nem.

We found no deficits in intellectual abilities (WISC-4 and Raven Progressive Matrices), which is consistent with the majority of previous studies (e. g. Croona et al., 1999; Danielsson and Petermann, 2009). There were also no differences between BECTS and control group in the visuo-spatial subtest of CMS. Children with BECTS had no difficulties in learning spatial arrangements (CMS-dot locations), recalling locations of homogenous objects (CMS-pictures locations) or memorizing scenes with a few persons (CMS-family pictures). Thus, it seems that children with BECTS have no impairments in basic? Vagyis single-modality? Basic vs combined? Ezeket az ellenteteket rendbe kell esetleg tenni visuo-spatial short-term memory test.

In order to explore memory integration processes in BECTS, binding tasks with different complexity levels were used in our study. We found that children with BECTS have no deficit in recalling spatial locations of distinct objects (binding of what and where), remembering temporal order of pictures (binding of what and when) or maintaining sequential order of homogenous items (binding of where and when). Thus, it seems that performance in short-term memory tasks in a single modality (and with a single binding) is unaffected by the epileptic syndrome.

We also investigated multiple binding processes. Our results showed that children with BECTS had lower scores in combined task than control group. The fact that we haven't found lower scores in the task where participants had to integrate only spatial and temporal information (binding of where and when) implies that the cause of the deficit is not the integration of spatial and temporal information, but rather the binding between several modalities - more precisely the binding of spatial sequence and verbal order of objects. 
In summarizing, it emerged that binding processes within a single modality? are not impaired in BECTS which suggest that children with BECTS have no specific short-term memory deficits. However their impairment in the combined task implies the presence of other kind of high-level cognitive deficits in BECTS.

The combined task demands complex cognitive functions such as divided attention or manipulation with information from more than one source, which emphasizes the possible executive function deficit behind memory weakness in BECTS. Several previous studies have confirmed the existence of executive function deficits in BECTS (e. g. D'Alessandro et al., 1990; Croona et al., 1999; Giordani et al., 2006; Pinton et al., 2006; Ay et al., 2009). Praline et al. (2003) argue that focal epileptic activity produces disturbances in the maturation of cortical zones, mainly in the associative areas. Kanemura and Aihara (2009) and Kanemura et al. (2011) have shown frontal lobe disturbances in serious cases of BECTS.

Based on our present results, it seems that the dynamic integration of spatial and verbal information in working memory is a higher-level process than the binding processes within a single modality (spatial or verbal). Opitz (2010) argues that high-level binding processes are related to not only the medio-temporal lobe, but also to the prefrontal cortical areas. Velik (2009) also distinguishes two separate binding forms: one is mediated by attention while the other can function without attention. The multiple integration processes of the combined task may demand conscious attention, which is related to/controlled by the prefrontal lobe. This assumption is confirmed by the fact that increased complexity of task demands such as contextual integration elicits greater involvement of frontal regions (Simons et al., 2005; Stuss, 2006). Taken together, it seems that children with BECTS have difficulties with high-level memory integration processes but they have no deficits in automatic binding processes.

In this study we demonstrated that children with BECTS have difficulties in memory tasks, which involve cognitive effort. We suggest that the inherent frontal lobe functions within complex working memory tasks might be a possible explanation of the controversial results of previous studies in memory function of BECTS. Taken together, our results imply no specific memory dysfunction in BECTS; rather, the difficulties children with BECTS experience lie in the conscious organization of information within memory. Even though the epileptic spikes are related to the centrotemporal area of the brain, the syndrome might also affect the prefrontal lobe. Based on these results, further studies should examine the role of frontal lobe functions in memory performance of children with BECTS. 
Acknowledgment: This study was supported by the National Scientific Research Foundation, Hungary, Realistic approach to memory: Healthy and impaired memory functions, 2010bb02012, K-81641)

\section{REFERENCES}

Ay, Y., Gokben, S., Serdaroglu, G., Polat, M., Tosun, A., Tekgul, H., Solak, U., Kesikci, H. (2009). Neuropsychologic Impairment in Children with Rolandic Epilepsy. Pediatric Neurology, 41(5), 359-363.

Baddeley, A. (2009) Working memory. In Baddeley, A., Eysenck, M.W., Anderson M.C. (eds.) Memory, Psychology Press, Hove and New York.

Bates, E., D’Amico, S., Jacobsen, T., Székely, A., Andonova, E., Devescovi, A., Herron, D.,Ching LU, C., Pechmann, T., Pléh, Cs., Wicha, N., Federmeier, K., Gerdjikova, I., Gutierrez, G., Hung, D., Hsu, J., Iyer, G., Kohnert, K., Mehotcheva, T., Orozco-Figueroa, A., Tzeng, A.,Tzeng, O. (2003). Timed picture naming in seven languages. Psychonomic Bulletin and Review, 10(2), 344-380.

Cohen, M. J. (1997). Children's Memory Scale. San Antonio, TX: The Psychological Corporation, Harcourt Brace \& Company.

Croona, C., Kihlgren, M., Lundberg, S., Eeg-Olofsson, O., Eeg-Olofsson, K.E. (1999) Neuropsychological findings in children with benign childhood epilepsy with centrotemporal spikes. Developmental Medicine \& Child Neurology, 41, 813-818.

D'Alessandro, P., Piccirilli, M., Tiacci, C., Ibba, A., Maiotti, M., Sciarma, T., Testa A. (1999) Neuropsychological features of benign partial epilepsy in children. The Italian Journal of Neurological Sciences, 11(3), 265-269.

Danielsson, J., Petermann, F. (2009). Cognitive deficits in children with benign rolandic epilepsy of childhood or rolandic discharges: A study of children between 4 and 7 years of age with and without seizures compared with healthy controls. Epilepsy \& Behavior, 16, 646-651.

Giordani, B., Caveney, A.F., Laughrin, D., Huffman, J.L., Berent, S., Sharma, U., Giles, J.M, Garofalo, E.A. (2006). Cognition and behavior in children with benign epilepsy with centrotemporal spikes (BECTS). Epilepsy Research, 70, 89-94.

Goldberg-Stern, H., Gonen, O.M., Sadeh, M., Kivity, S., Shuper, A., Inbar, D. (2010). Neuropsychological aspects of benign childhood epilepsy with centrotemporal spikes, Seizure 19, 12-16. 
Heijbel, J., Bohman, M. (1975) Benign Epilepsy of Children with Centrotemporal EEG Foci: Intelligence, Behavior, and School Adjustment, Epilepsia, 16(5), 679-687.

Kanemura, H., Aihara, M. (2009). Growth disturbance of frontal lobe in BCECTS presenting with frontal dysfunction. Brain Development, 31, 771-774.

Kanemura, H., Hata, S., Aoyagi, K., Sugita, K., Aihara, M. (2011). Serial changes of prefrontal lobe growth in the patients with benign childhood epilepsy with centrotemporal spikes presenting with cognitive impairments/behavioral problems. Brain \& Development, 33, 106-113.

Kárpáti J., Király I., Kónya, A. (2013). A tér-idői emlékezet fejlődése téri szekvencia és fogalmi sorrend integrációja a munkamemóriában. Pszichológia. 33(3), 185-204.

Nagyné Réz, I., Lányiné Engelmayer, Á., Kuncz, E., Mészáros, A., Mlinkó, R. (2008). Wechsler Intelligence Scale for Children-Fourth Edition. Magyar Adaptáció [Hungarian adaptation]. Budapest: OS-Hungary.

Northcott, E., Connolly, A.M., Berroya, A., Sabaz, M., McIntyre, J., Christie, J., Taylor, A., Batchelor, J., Bleasel, A.F., Lawson, J.A., Bye, A.M.E. (2005). The neuropsychological and Language Profil of Children with Benign Rolandic Epilepsy. Epilepsia, 46(6), 924-930.

Northcott, E., Connolly, A.M., Berroya, A., McIntyre, J., Christie, J., Taylor, A., Bleasel, A.F., Lawson, J.A., Bye, A.M.E. (2007). Memory and phonological awareness in children with Benign Rolandic Epilepsy compared to a matched control group. Epilepsy Research, 75, 57-62.

Opitz, B. (2010). Neural binding mechanisms in learning and memory. Neuroscience and Biobehavioral Reviews, 34, 1036-1046.

Pinton, F., Ducot, B., Motte, J., Arbués, A.S., Barondiot, C,, Barthez, M.A., Chaix, Y., Cheminal, R., Livet, M.O., Penniello, M.J., Peudenier, S., de Saint-Martin, A., Billard, C. (2006). Cognitive functions in children with benign childhood epilepsy with centrotemporal spikes (BECTS). Epileptic Disorders, 8(1), 11-23.

Postma, A., Asselen, M.Van, Keuper, O., Wester, A.J., Kessels, R.P.C. (2006). Spatial and temporal order memory in Korsakoff patients. Journal of the International Neuropsychological Society, 12(3), 327-336.

Praline, J., Hommet, C., Barthez, M.A., Brault, F., Perrier, D., Passage, G.D., Lucas, B., Bonnard, J., Billard, C., Toffol, B. D., Autret, A. (2003). Outcome at adulthood of the continuous spike-waves during slow sleep and Landau-Kleffner syndrome. Epilepsia, 44, $1434-1440$.

Raven, J.C., Court, J.H., Raven, J. (1990). Coloured Progressive Matrices. Raven Manual, Section 2. Oxford Psychologists Press.

Raven, J.C., Court, J.H., Raven, J. (1996). Standard Progressive Matrices. Raven Manual, Section 3. Oxford Psychologists Press. 
Simons, J.S., Gilbert, S.J., Owen, A.M., Fletcher, P.C., Burgess, P.W. (2005). Distinct roles for lateral and medial anterior prefrontal cortex in contextual recollection. Journal of Neurophysiology, 94, 813-820.

Stuss, D. T. (2006). Frontal lobes and attention: Processes and networks, fractionation and integration, Journal of the International Neuropsychological Society, 12, 261-271.

Székely, A., Jacobsen, T., D’Amico, S., Devescovi, A., Andonova, E., Herron, D., Lu, Ch., Pechmann, T., Pléh, Cs., Wicha, N., Federmeier, K., Gerdjikova, I., Gutierrez, G., Hung, D., Hsu, J., Iyer, G., Kohnert, K., Mehotcheva, T., Orozco-Figueroa, A., Tzeng, A. Tzeng, O., Arevalo, A., Vargha, A., Butler, A.C., Buffington, R., Bates, E. (2004): A new on-line resource for psycholinguistic studies. Journal of Memory and Language, 51(2), 247-250.

Vago, C., Bulgheroni, S., Franceschetti, S., Usilla, A., Riva, D. (2008). Memory performance on the California Verbal Learning Test of children with benign childhood epilepsy with centrotemporal spikes. Epilepsy \& Behavior 13, 600-606.

Velik, R. (2009): From single neuron firing to consciousness: Towards the true solution of the binding problem. Neuroscience and Biobehavioral Reviews, 34(7), 993-1001.

Verrotti, A., D’Egidio, C., Agostinelli, S., Parisi, P., Chiarelli, F., Coppola, G. (2011). Cognitive and linguistic abnormalities in benign childhood epilepsy with centrotemporal spikes, Acta Pediatrica, 100, 768-772.

Völkl-Kernstock, S. Willinger, U., Feucht, M. (2006). Spacial perception and spatial memory in children with benign childhood epilepsy with centro-temporal spikes (BCECTS), Epilepsy Research 72, 39-48.

Weglage, J., Demsky, A., Pietsch, M., Kurlemann, G. (1997). Neuropsychological, intellectual and behavioral findings in patients with centrotemporal spikes with and without seizures. Developmental Medicin and Child Neurology, 39, 646-651.

\section{APPENDIX}

Appendix 1. Descriptions of the CMS subtests

\begin{tabular}{|l|l|}
\hline Dot Locations & $\begin{array}{l}\text { The stimulus item consisting of blue dots placed within a white box. The examiner } \\
\text { shows the spatial arrangement to the child for } 5 \text { seconds and ask him/her to remember } \\
\text { the dots' positions. Immediately after the exposure the examiner ask the child to place } \\
\text { blue chips within a grid as he or she remembered where the dots were within the box. } \\
\text { The examiner repeats the same procedure twice. Thereafter the examiner shows a new } \\
\text { arrangement with red dots as an interference and right after the child reconstructed it, } \\
\text { the examiner ask to recall the old one once again. The spatial arrangement consists of } 6 \\
\text { dots between the ages of } 5 \text { to } 8 \text { years and } 8 \text { dots between the ages of } 9 \text { to } 16 .\end{array}$ \\
\hline Family pictures & $\begin{array}{l}\text { The examiner shows a family portrait and identify the family members. Then the } \\
\text { examiner presents scenes from the family's life and ask the child to remember as much } \\
\text { as she or he can about the scene. After the } 10 \text { seconds exposure the examiner shows the } \\
\text { same scene except the family members are missing. The examiner ask to recall which } \\
\text { family members were in the picture, what they were doing and where they were in it. } \\
\text { The subtest consist of four scenes (picnic scene, department scene, yard scene and meal } \\
\text { scene) for children in all ages. }\end{array}$ \\
\hline
\end{tabular}




\begin{tabular}{|l|l|}
\hline Picture locations & $\begin{array}{l}\text { The examiner shows a stimulus page with pictures placed in various locations within a } \\
\text { box. Immediately after the exposure the examiner ask the child to place the response } \\
\text { chips on the response grid as he or she remembered where the presented pictures were } \\
\text { within the box. The task starts with the presentation of two items and after every two } \\
\text { trials sequence increase with one object up to maximum of } 5 \text { objects in children } \\
\text { between the ages of } 5 \text { to } 8 \text { and to } 8 \text { objects in children between the ages of } 9 \text { to 16. In } \\
\text { all trials the pictures are homogeneous (animals or vehicles). }\end{array}$ \\
\hline
\end{tabular}

\section{Appendix 2. Description of the control task}

This task was used in the beginning and in the end of computerized tasks as a control task for measuring fatigue during the tasks. Black dots appear serially in various locations on the screen. Each item appears for $1500 \mathrm{msec}$. After the presentation the same dots reappear simultaneously in their original positions. Participant has to click on the dots in the order they were presented initially.

\section{Appendix 3. Instructions of binding tasks}

\begin{tabular}{|c|c|}
\hline $\begin{array}{c}\text { Task's name } \\
\text { (presentation-recall) }\end{array}$ & Instructions \\
\hline $\begin{array}{c}\text { Spatial task } \\
\text { (spatial presentation } \\
\text { with distinct pictures - } \\
\text { spatial recall with } \\
\text { distinct pictures) }\end{array}$ & $\begin{array}{c}\text { In this test, objects will appear on the screen. } \\
\text { The number of objects will increase with each trial. } \\
\text { Try to remember the location of each of the objects. } \\
\text { After the presentation you have to relocate them to their original positions. } \\
\text { In the beginning of the task you will have some practice trials. }\end{array}$ \\
\hline $\begin{array}{l}\text { Verbal task } \\
\text { (temporal presentation } \\
\text { with distinct pictures - } \\
\text { recall by putting } \\
\text { distinct objects into a } \\
\text { box in the center of the } \\
\text { screen) }\end{array}$ & $\begin{array}{l}\text { In this test, objects will appear on the screen. } \\
\text { The number of objects will increase with each trial. } \\
\text { Try to remember the temporal order of the objects. } \\
\text { After the presentation you have to put them into a box in the same temporal } \\
\text { order as they were presented originally. } \\
\text { You will have some practice trials in the beginning. }\end{array}$ \\
\hline $\begin{array}{l}\text { Spatial sequential } \\
\text { task } \\
\text { (spatio-temporal } \\
\text { presentation with } \\
\text { distinct pictures - } \\
\text { spatio-temporal recall } \\
\text { with homogenous dots) }\end{array}$ & $\begin{array}{l}\text { In this test, objects will appear on the screen. } \\
\text { The number of objects will increase with each trial. } \\
\text { Try to remember the order of the objects. } \\
\text { After the presentation you have to click on black dots in the same order as the } \\
\text { objects were presented originally. } \\
\text { You will have some practice trials in the beginning. }\end{array}$ \\
\hline $\begin{array}{l}\text { Combined task } \\
\text { (spatio-temporal } \\
\text { presentation with } \\
\text { distinct pictures - } \\
\text { spatio-temporal recall } \\
\text { with distinct pictures) }\end{array}$ & $\begin{array}{l}\text { In this test, objects will appear on the screen. } \\
\text { The number of objects will increase with each trial. } \\
\text { Try to remember both the order and the locations of the objects. } \\
\text { After the presentation you have to rearrange them to the same place and in the } \\
\text { same order as they were originally. } \\
\text { You will have some practice trials in the beginning. }\end{array}$ \\
\hline Control task & $\begin{array}{l}\text { In this test, black dots will appear on the screen. } \\
\text { The number of black dots will increase with each trial. }\end{array}$ \\
\hline
\end{tabular}


(spatio-temporal presentation with homogenous dots spatio-temporal recall with homogenous dots)
Try to remember the order of the dots.

After the presentation you have to click on the dots in the same order as they were presented originally.

You will have some practice trials in the beginning. 